\title{
Attacin A Gene from Tricloplusia ni Reduces Susceptibility to Xanthomonas axonopodis pv. citri in Transgenic Citrus sinensis 'Hamlin'
}

\author{
Raquel L. Boscariol \\ Universidade de São Paulo, Centro de Energia Nuclear na Agricultura, 13400-970, Piracicaba/SP, \\ Brazil
}
Mariza Monteiro, Elizabete K. Takahashi, Sabrina M. Chabregas, and Maria Lucia C. Vieira Universidade de São Paulo, Escola Superior de Agricultura “Luiz de Queiroz”, 13418-900, Piracicabal SP, Brazil

\author{
Luiz G.E. Vieira and Luiz F.P. Pereira \\ Instituto Agronômico do Paraná, 86001-970, Londrina/PR, Brazil
}

Francisco de A.A. Mourão Filho, Suane C. Cardoso, Rock S.C. Christiano, Armando Bergamin Filho, Janaynna M. Barbosa, and Fernando A. Azevedo

Universidade de São Paulo, Escola Superior de Agricultura “Luizde Queiroz”, 13418-900, Piracicabal SP, Brazil

\begin{abstract}
Beatriz M.J. Mendes ${ }^{1}$
Universidade de São Paulo, Centro de Energia Nuclear na Agricultura, 13400-970, Piracicaba/SP, Brazil
\end{abstract}

\begin{abstract}
AdDitional INDEX WORDs. antibacterial peptide, Agrobacterium tumefaciens, citrus canker, sweet orange
Abstract. Citrus canker, caused by Xanthomonas axonopodis Starr and Garces pv. citri (Hasse) Vauterin et al., is one of the main problems affecting citrus production. In order to obtain resistance to phytopathogenic bacteria, insect genes, coding for antimicrobial proteins, have been used in plant genetic transformation. In this study, transgenic Citrus sinensis (L.) Osb. 'Hamlin' plants expressing the antimicrobial insect-derived attacin A gene (attA) were obtained by Agrobacterium tumefaciens (Smith and Towns.) Conn-mediated transformation. Initially, the cDNA clone was used to construct a binary plasmid vector ( $\mathrm{pCattA}$ 2300). The construction included the native signal peptide (SP) responsible for directing the insect protein to the extracellular space where bacteria is supposed to accumulate in vivo. In order to investigate the native SPeffectiveness in a plant model system, onion (Allium cepa L.) epidermal cells were transformed, via biobalistics, using plasmids containing the attA gene with or without SP, fused with the green fluorescent protein gene (pattA 1303 and pSPattA 1303). Fluorescence accumulation surrounding the cells was observed only in tissues transformed with the plasmid containing the gene with SP, indicating the protein secretion to the apoplast. Citrus transformation was confirmed by PCR and Southern blot hybridization analysis in 12 regenerated plants. Transcription of attA gene was detected by Northern blot analysis in all transgenic plants. Eight selected transgenic lines were propagated and inoculated with $\mathbf{a}^{6} \mathrm{cfu} / \mathrm{mL}$ suspension of the pathogen $X$. axonopodis pv. citri. Compared to control (non-transformed plant), seven transgenic lines showed a significant reduction in susceptibility to citrus canker. The results obtained here indicate the potential use of antibacterial proteins to protect citrus from bacterial diseases.
\end{abstract}

Attacins belong to a class of antimicrobial peptides of around $20 \mathrm{kD}$, which are secreted into the insects haemolymph in response to bacterial infection (Engström et al., 1984). These proteins act on the outer membrane of gram-negative bacteria by altering permeability and the synthesis of proteins (Carlsson et al., 1998). Attacins exist in both basic (A, B, C, D) or acidic forms (E, F) (Hultmark et al., 1983).

The genes encoding these proteins have been isolated from

\footnotetext{
Received for publication 23 Nov. 2005. Accepted for publication 30 Apr. 2006. The authors acknowledge FAPESP for research financial support and fellowship to R.L.Boscariol; Drs. M.C. Silva-Filho and M.L.R. Aguiar Perecin for consenting to the use of their laboratories; and P.A.S. Marbach and M.C. Falco for technical assistance.

'To whom reprint requests should be addressed. E-mail address: beatriz. mendes@pesquisador.cnpq.br
}

insects such as Hyalophora cecropia L. (attacin E) (Sun et al., 1991), Drosophila melanogaster Meigen (attacin A) (Asling et al., 1995) and Tricloplusia ni Hübner (attacin A) (Kang et al., 1996). Attacin A, from T. ni, is a 1601-bp gene, with two introns, starting with a signal peptide. On both nucleotide and peptide level T. $n i$ attacin shows homology to the attacin-like proteins, such as $H$. cecropia acidic attacin, with $63 \%$ identity in the mature part (Kang et al., 1996).

Insect genes coding for antimicrobial proteins have been used in plant genetic transformation for obtaining resistance to phytopathogenic bacteria (Reynoird et al., 1999; Sharma et al., 2000). Transgenic pear (Pyrus communis L.) (Reynoird et al., 1999), apple [Malus $\times$ sylvestris (L.) Mill var. domestica (Borkh.) Mansf.] (Ko et al., 2000, 2002), and potato (Solanum tuberosum L.) plants (Arce et al., 1999) expressing the acidic attacin E protein gene from $H$. cecropia showed a reduced susceptibility 
to Erwinia amylovora (Burr.) Winslow et al. and E. carotovora (Jones 1901) Bergey et al. pv. atroseptica (van Hall) Dye.

Phytopathogenic bacteria normally multiply in the intercellular space before attacking plant cells (Alfano and Collmer, 1996). Therefore, the effectiveness of the transgene in conferring resistance depends not only on their expression level and stability in plant tissues (Mourgues et al., 1998) but also on the appropriate heterologous protein accumulation location (Ko et al., 2000). The association of a signal peptide element with the transgene in order to direct the antibacterial proteins to the intercellular space may help prevention of colonization of plant tissue by phytopathogenic bacteria (Carlsson et al., 1998). A homology search, by nucleotide sequence alignment using BLAST analysis, indicated that attA gene is associated with a signal peptide responsible for directing the attacin protein to endoplasmic reticulum for secretion. Proteins synthesized on membranes of endoplasmic reticulum-associated ribosomes are dispatched to their final destinations by specific targeting sequences, i.e., the signal peptides. According to SilvaFilho (2003), the sorting of these proteins is highly efficient. It seems to be the case of the $\operatorname{att} \mathrm{A}$, which is directed to the insect haemolymph. The presence of protein in the apoplast should provide the best protection against phytopathogenic bacteria. The plant model system (epidermial onion cells) and the green fluorescent protein ( $g f p$ ) technology (Brandizzi et al., 2004) were used to investigate the possibility that attA gene transformed cells can direct the protein to endoplasmic reticulum or Golgi, where it is sorted for secretion.

Citrus genetic transformation for disease resistance has been done for virus protection using genes isolated from citrus tristeza virus (Domínguez et al., 2000, 2002; Fagoaga et al., 2006) and for Phytophthora citrophthora (Sm. et Sm.) Leonian resistance expressing a tomato pathogenesis related protein PR-5 (Fagoaga et al., 2001). Citrus canker, which is caused by $X$. axonopodis $\mathrm{pv}$. citri, is one of the main problems affecting citrus production in Brazil. The disease has been controlled through an eradication program but new disease foci are regularly identified. The objective of this study was to introduce the attA gene, isolated from T. ni (Kang et al., 1996), into C. sinensis 'Hamlin'. Its potential in inhibiting $X$. axonopodis pv. citri development in transgenic citrus plants was evaluated.

\section{Material and Methods}

VECTOR CONSTRUCTIONS AND $A$. TUMEFACIENS TRANSFORMATION. pFFattA: the attA gene, from $T$. ni, was kindly provided by A. Lundström (Department of Microbiology, Stockholm University, Sweden). The gene was cloned in the pBlueScript II KS(+) and was digested with SacI (5' end) and KpnI (3' end). A 1050-bp fragment corresponding to the attA gene cDNA was recovered and inserted in the pUC-derived multiple cloning site (MCS) of pFF19 (4.2 kb), between the cauliflower mosaic virus 35S-35S promoter and 35S terminator (Timmermans et al., 1990) to create pFFattA. Plasmid DNA was transferred to Escherichia coli Escherich (DH5 $\alpha$ ) cells (Brasileiro and Carneiro, 1998), and the transformation was confirmed by PCR using the primers: forward 5' GCT GTT CAG CTA GCC AGT CC 3', and reverse 5' TTT GGG AAG TCA GGC ATG TT 3' that amplify a 350-bp fragment from the attA gene. The PCR reactions were performed in a thermal cycler (MJ Research, Watertown, Mass.) under the following conditions: $3 \mathrm{~min}$ at $94{ }^{\circ} \mathrm{C}$ for the first denaturation, followed by 40 cycles of $1 \mathrm{~min}$ at $94^{\circ} \mathrm{C}, 1.5 \mathrm{~min}$ at $55^{\circ} \mathrm{C}$, and 1 min at $72{ }^{\circ} \mathrm{C}$, with a final extension of 4 min at $72{ }^{\circ} \mathrm{C}$. Plasmid
DNA was purified with a Plasmid Mini Kit (Qiagen Inc., Valencia, Calif.), quantified and stored at $-20{ }^{\circ} \mathrm{C}$. Transformed colonies were cultivated and stored in glycerol at $-80^{\circ} \mathrm{C}$.

pCattA 2300: 35S-35S-attA-35ST expression cassette was excised from pFFattA by total digestion with HindIII, followed by partial digestion with EcoRI (0.4 U, 20 min, $6 \mu$ g plasmid DNA), and then cloned into pCambia 2300 binary vector (CAMBIA, Canberra,Australia). This vector carries the selective marker gene $n p t$ II. Plasmid DNA was transferred to E. coli and the transformation was confirmed as previously mentioned. The plasmid pCattA 2300 was transferred by freeze-thaw method to A. tumefaciens EHA105 cells (Brasileiro and Carneiro, 1998).

pSPattA 1303 and pattA 1303: In order to investigate the signal peptide (SP) effectiveness in dispatching the attacin protein to the plant cells extracellular space, plasmids containing the attA gene with and without the native SP were constructed. Initially, three primers (29 bp) were designed (two forward and one reverse) based on the preproattacin A corresponding sequence from T. ni (GenBank U46130). Forward 1 and 2 were designed to amplify the sequences with (765 bp) and without (711 bp) SP (54 bp), respectively (Table 1$)$. PCR reaction $(50 \mu \mathrm{L})$ contained $500 \mathrm{ng}$ of pCattA 2300 plasmidial DNA, $10 \mathrm{~mm}$ Tris- $\mathrm{HCl}(\mathrm{pH}$ 8.4), $50 \mathrm{~mm} \mathrm{KCl}, 3.0 \mathrm{~mm} \mathrm{MgCl}_{2}, 30 \mu \mathrm{M}$ of each dNTP, $1.0 \mathrm{U}$ of Taq DNA polymerase (Invitrogen, Carlsbad, Calif.) and $0.6 \mu \mathrm{M}$ from each of the specific primers. The PCR procedure was the same as described above. The sequences were cleaved with SpeI ( 3 ' end), followed by a partial digestion with $\mathrm{NcoI}$ (5' end). PCR products (766 bp and $712 \mathrm{bp}$ ) were submitted to electrophoresis and the fragments were inserted into pCambia 1303, resulting in the constructions 35S-SPattA::uidA::gfp-Nos and 35S-attA:: uidA::gfp-Nos, which were named pSPattA 1303 and pattA 1303, respectively. The plasmids and a negative control were transferred to E. coli (JM109) and utilized in biobalistics procedures.

AtTACIN A PROTEIN CELLULAR LOCALIZATION IN PLANT TISSUES. Epidermial onion cells were transformed with pSPattA 1303 and pattA 1303 via biobalistics (PDS-1000/He, BioRad, Hercules, Calif.). $\mathrm{CaCl}_{2}$ /spermidine method (Aragão et al., 1996; Smith et al., 1992) was used for DNA precipitation on the tungsten particle (M10; Sylvania, Danvers, Mass.). Onion epidermis segments (2 $\left.\mathrm{cm}^{2}\right)$, placed on the central part of petri dishes $(90 \times 15 \mathrm{~mm})$, were bombarded. The chamber air humidity was lower than $40 \%$ and the vacuum higher than $8.7 \mathrm{kPa}$. The physical parameters were set as follows: helium pressure $6.2 \mathrm{MPa}$; distance to the target 6 $\mathrm{cm}$; distance between rupture disk and macrocarrier $6.35 \mathrm{~mm}$; and distance between macrocarrier and stopping screen $10 \mathrm{~mm}$. Four bombardments were carried out, with three explants each. pCambia 1303 was used as control. Explants were incubated in the dark for $24 \mathrm{~h}$, at $25^{\circ} \mathrm{C}$. For $g f p$ expression analysis, explants were transferred to glass slides, plasmolyzed with $5 \mathrm{M} \mathrm{NaCl}_{2}$, and observed under a fluorescence microscope (Axiophot 2; Zeiss, Oberkochen, West Germany) equipped with a FITC filter (excitation $470 \mathrm{~nm}$; emission $520 \mathrm{~nm}$ ).

AGROBACTERIUM TUMEFACIENS-MEDIATED TRANSFORMATION of C. SINENSIS 'HAMLIN'. Epicotyl segments collected from in

Table 1. Primer sequences designed for cloning the attA gene with and without the native signal peptide into pCambia 1303. Restriction sites are underlined. Superscript numbers correspond to attA gene original positions (GenBank U46130).

Forward $15^{\prime} \mathrm{CCC} \mathrm{CCA} \mathrm{TGG} \mathrm{AAA}^{1}$ TGT TCA CCT ACA AAT TG 3

Forward $25^{\prime} \mathrm{CCC}$ CCA TGG $\mathrm{CCC}^{54}$ GTT ATT TGG TCT TTG AA 3'

Reverse' 5' CCC ACT AGT $^{763}$ CCA CTT ATT ACC AAA AGA CC 3' 
vitro germinated seedlings (Boscariol et al., 2003) were used as explants for transformation. Explants were inoculated with A. tumefaciens EHA 105 containing pCattA 2300, for $25 \mathrm{~min}$. After inoculation, the explants were blotted dry and transferred to EME medium (Grosser and Gmitter, 1990) supplemented with benzylaminopurine-BAP $\left(1 \mathrm{mg} \cdot \mathrm{L}^{-1}\right)$ for a 3 -d co-cultivation period, at $24{ }^{\circ} \mathrm{C}$. After co-cultivation, explants were transferred to selection medium consisting of EME medium supplemented with BAP $\left(1 \mathrm{mg} \cdot \mathrm{L}^{-1}\right)$, kanamycin $\left(100 \mathrm{mg} \cdot \mathrm{L}^{-1}\right)$ and cefotaxime $\left(500 \mathrm{mg} \cdot \mathrm{L}^{-1}\right)$. Cultures were incubated in the dark for 4 weeks, at $27^{\circ} \mathrm{C}$, and then transferred to 16 -h photoperiod $\left(63 \mu \mathrm{mol} \cdot \mathrm{m}^{-2} \cdot \mathrm{s}^{-1}\right)$ at $27 \pm 1^{\circ} \mathrm{C}$.

Molecular analysis of Transgenic Plants. Genomic DNA was extracted (Doyle and Doyle, 1990) from leaves of welldeveloped in vitro shoots and evaluated to detect the presence of the 350-bp fragment, using the above mentioned primer pair. The PCR recipe was: 50-60 ng DNA, $100 \mu \mathrm{M}$ of each dNTP, 5 $\mathrm{mM} \mathrm{MgCl}_{2}, 0.2 \mu \mathrm{M}$ of each primer, and $1 \mathrm{U}$ Taq DNA polymerase (Promega, Madison, Wis.). Reactions were performed under the following conditions: $5 \mathrm{~min}$ at $95{ }^{\circ} \mathrm{C}$ for the first denaturation, followed by 35 cycles of $1 \mathrm{~min}$ at $95{ }^{\circ} \mathrm{C}, 40 \mathrm{~s}$ at $55^{\circ} \mathrm{C}$, and $30 \mathrm{~s}$ at $72{ }^{\circ} \mathrm{C}$, with a final extension of $5 \mathrm{~min}$ at $72{ }^{\circ} \mathrm{C}$. The primers 5' CTG GCG GCA AAG TCT GAT 3' and 5' TGT CGT AAA CCT CCT CGT 3' (Negrotto et al., 2000) were used to amplify a 450-bp fragment of the virG gene and detect possible plant tissue contamination with $A$. tumefaciens. PCR reactions were performed as follows: $2 \mathrm{~min}$ at $96^{\circ} \mathrm{C}$ for the first denaturation, followed by 35 cycles of $15 \mathrm{~s}$ at $94{ }^{\circ} \mathrm{C}, 30 \mathrm{~s}$ at $53{ }^{\circ} \mathrm{C}$, and $30 \mathrm{~s}$ at $72{ }^{\circ} \mathrm{C}$, with a final extension of $5 \mathrm{~min}$ at $72^{\circ} \mathrm{C}$. PCR-positive shoots were carefully excised from the explants and micrografted in vitro onto Carrizo citrange $[C$. sinensis $\mathrm{x}$ Poncirus trifoliate (L.) Raf.] seedlings (Peña et al., 1995) for plant development and further analysis. The transformation efficiency was expressed as the percentage of PCR-positive plants in relation to the total number of explants exposed to A. tumefaciens.

Citrus genetic transformation was confirmed by Southern blot analysis. Genomic DNA was isolated from fully expanded leaves of acclimatized plants using Plant DNAzol reagent protocol (Invitrogen). BamHI or HindIII-digested DNA samples $(20 \mu \mathrm{g})$ were separated on $1 \%$ agarose gel by electrophoresis and transferred to nylon membrane (Hybond-N+; Amersham Biosciences, Buckinghamshire, England). HindIII cuts the T-DNA once outside the gene area and $\mathrm{BamHI}$ isolates a 1050-bp fragment corresponding to gene cDNA. A 1050-bp digested fragment fluorescein-labelled (Gene Images Random Prime Labelling Module; Amersham Biosciences) was used as a probe. The hybridization, washing and detection were performed with Gene Images CDP-Star Detection Module (Amersham Biosciences) following the manufacture's instructions. Transcription of attA gene in transgenic plants was determined by Northern blot analysis. Total leaf RNA was isolated from transgenic acclimatized plants and a non-transformed control plant using TRIzol reagent protocol (Invitrogen). Fifteen micrograms of RNA of each sample were electrophoresed in a denaturing $1 \%$ agarose gel. The separated RNAs were transferred to a nylon membrane (Hybond; Amersham Biosciences). Transgene RNA was detected by hybridization with a fluorescein-labelled probe as described for Southern blot analysis.

EVALUATION FOR RESISTANCE TO $\boldsymbol{X}$. AXONOPODIS PV. CITRI. Eight transgenic plants and a non-transgenic control plant were selected, based on the vegetative development and adequate budwood for grafting. For propagation, 30 well-developed buds, of each plant, were grafted onto Cleopatra mandarin ( $C$. reticulata Blanco) rootstock plants cultivated in small tubes $(19.5 \times 5.0 \mathrm{~cm})$ containing pinus bark substrate. After a 2 -month incubation period 7-10 plants per transgenic line and control were selected, based on leaf phenology, in order to favor stomatal bacteria penetration (Viloria et al., 2004). Each plant were individually spray-inoculated with a $10^{6} \mathrm{cfu} / \mathrm{mL} X$. axonopodis pv. citri suspension and incubated in a growth room, with restricted access, at $27^{\circ} \mathrm{C}$ under 16-h photoperiod. Disease severity was determined $30 \mathrm{~d}$ after inoculation. The images of two youngest leaves per plant (total of 15 leaves per transgenic line) were digitalized and the leaf and diseased area were calculated using QUANT 1.0 software (Vale et al., 2001). The experiment followed a completely randomized design and was repeated three times. The data were analyzed by analysis of variance.

\section{Results}

VECTOR CONSTRUCTIONS AND $\boldsymbol{A}$. TUMEFACIENS TRANSFORMATION. The cDNA of the attA gene (1050 bp) was successfully isolated from pBlueScript II KS(+) and cloned into pFF19 (4.2 kb). The expression cassette $(2.1 \mathrm{~kb})$ was isolated and inserted into pCambia vector. Ligation direction was confirmed by sequencing (data not shown). The plasmid pCattA 2300 (Fig. 1A) was successfully transferred to A. tumefaciens cells. The 765 and 711-bp fragments, corresponding to attA gene with and without SP, were amplified and inserted into pCambia 1303 vector resulting in the constructions p35S-attA::uidA::gfp-Nos (13.073 kb) and p35S-SPattA:: uidA::gfp-Nos (13.127 kb) (Fig. 1B-C).

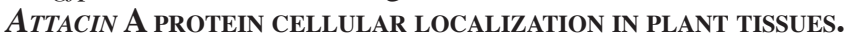
Fig. 2 shows the results obtained with onion epidermis transformation with both pattA 1303 and pSPattA 1303. Plasmolysis was induced to shrink the membrane and separate it from its cell wall (Fig. $2 \mathrm{~A}$ and C). Afluorescence accumulation was detected in the cytoplasm of pattA 1303 transformed cells (Fig. 2B). However, in tissues transformed with pSPattA 1303, which contained the SP, the fluorescence accumulation was observed surrounding the cell, indicating the protein secretion to the apoplast (Fig. 2D). No fluorescence accumulation was detected in non-transformed cells. These results confirm the effectiveness of SP expression in a heterologous organism. As the gene is of insect origin, this means that the large protein (attA fused with $g f p$ and $\beta$-glucoronidase genes) has been actively transported to the apoplast of the onion cells. The confirmation of protein transit and secretion encouraged the citrus genetic transformation and the evaluation for $X$. axonopodis pv. citri resistance.

TranSFORMATION AND MOLECULAR CHARACTERIZATION. Transformation with A.tumefaciens was performed on 150 C. sinensis 'Hamlin' explants. The explants incubation in the dark favored calli formation and indirect organogenesis. Adventitious shoots developed after $30 \mathrm{~d}$ of culture on selection medium. The presence of attA gene in the regenerated shoots was tested by PCR analysis at an early stage. Twenty-three regenerated shoot lines were evaluated and 21 showed amplification of the expected 350-bp fragment (14\% transformation efficiency) (Fig. 3A). Shoots, in which the cDNA sequence was PCR-identified, were grafted in vitro onto Carrizo citrange seedlings and developed into 12 whole plants. The PCR analysis using specific primers for the virG gene amplification confirmed the absence of $A$. tumefaciens contamination in the tissue (Fig. 3B). Micrografted plants with four to five leaves were acclimatized and transferred to a greenhouse.

Integration of attA gene was assured by Southern blot analy- 
A. pCattA 2300

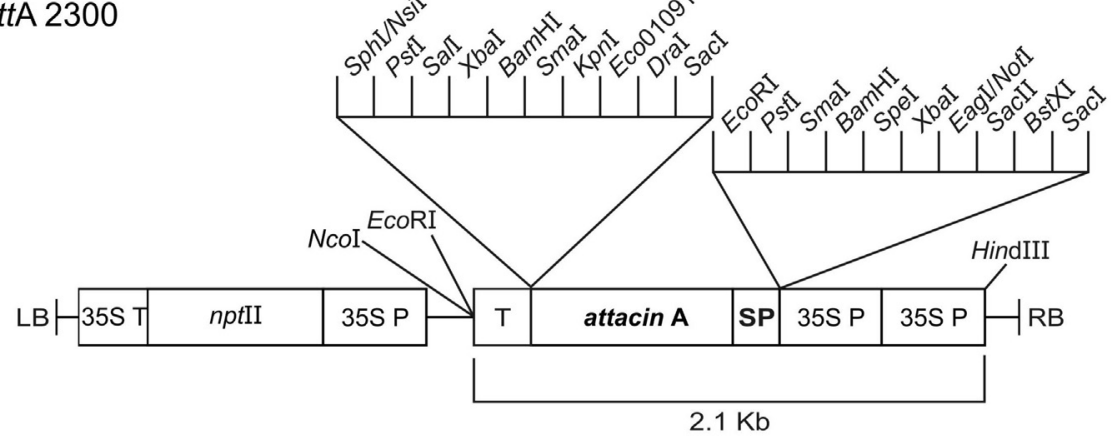

B. pattA 1303

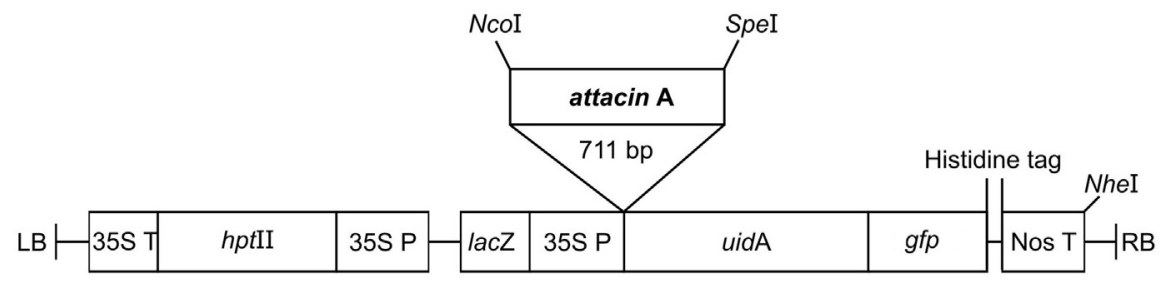

C. pSPattA 1303

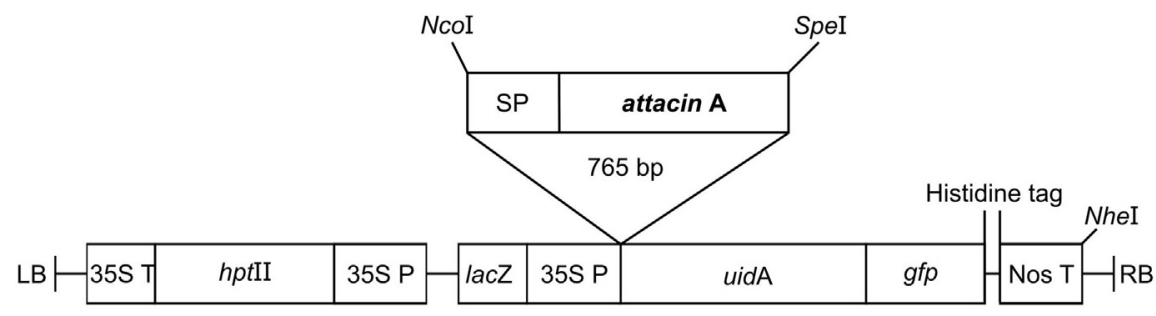

Fig. 1. Schematic representation of gene constructions used for genetic transformation. pCattA 2300 binary vector (A) used for Agrobacterium tumefaciens-mediated citrus transformation. pattA 1303 (B) and pSPattA 1303 (C) used for studying the attacin A protein sorting in epidermal onion cells. LB = left border; RB = right border; $35 \mathrm{~S} \mathrm{P}$ and $35 \mathrm{~S} \mathrm{~T}=$ cauliflower mosaic virus $35 \mathrm{~S}$ promoter and terminator, respectively; Nos $\mathrm{T}=$ nopaline synthase gene terminator; $h p t \mathrm{II}=$ hygromycin resistance gene; $n p t \mathrm{II}=$ neomycin phosphotransferase II gene; uidA ß-glucoronidase gene; $g f p=$ green fluorescent protein gene; $\mathrm{SP}=$ signal peptide. were propagated and inoculated with a bacterial suspension. The first disease symptoms could be detected $4-5 \mathrm{~d}$ after inoculation in both transgenic and non-transgenic plants. Disease severity quantification, after $30 \mathrm{~d}$ of inoculation (Fig. 4) revealed that transgenic lines had increased resistance to $X$. axonopodis pv. citri (Fig. 5). Seven out of eight transgenic lines analyzed showed a statistically significant reduction in susceptibility to citrus canker. Lines T2, $\mathrm{T} 8$, and $\mathrm{T} 12$ showed a reduced disease severity by $55 \%$ to $60 \%$ compared to the non-transformed control line.

\section{Discussion}

Conventional breeding efforts have had limited success in the production of new citrus varieties resistant to diseases. The introduction of selected genes in plants, preserving the genetic background of original cultivar (During, 1996), seems to be a promising approach towards improving resistance of citrus cultivars against diseases caused by bacteria.

Among the strategies to genetically engineering disease resistance, the introduction of genes, encoding antibacterial peptides has been reported with success concerning the enhancement of bacterial disease resistance in agricultural crops (Arce et al., 1999; Ko et al., 2000; Reynoird et al., 1999). As bacteria enter and spread in plant cells via apoplast (Alfano and Collmer, 1996), secretion of the antibacterial protein to intercellular space should facilitate the interaction between the resistance protein and the pathogen. This prevents plant tissue colonization by the phytopathogenic bacteria (During, 1996), and protects sis. Both cut genomic DNA from 12 PCR positive lines and the pCattA plasmid positive control hybridized with the 1050-bp attA-probe (Fig. 3C-D). DNA digested with HindIII that cuts only once the T-DNA out of the gene, revealed that the analyzed plants had undergone one or two integration events (Fig. 3C) and come from independent transformation events. BamHI digestion of genomic DNA resulted in excision of the entire attA cDNA (Fig. 3D). No hybridizing bands were detected in DNA from the non-transformed control line (Fig. 3C-D).

Northern blot showed variable but detectable levels of attA transcript in all transgenic plants (Fig. 3E). In particular, lines T1, $\mathrm{T} 7, \mathrm{~T} 9$, and $\mathrm{T} 12$ showed very low transcription levels and lines T3, T4, T5 and T6 displayed high transcription levels. RNA was not detected in leaves from the non-transformed plant.

ASSAYS FOR RESISTANCE TO $X$. AXONOPODIS PV. CITRI. To examine the susceptibility to $X$. axonopodis pv. citri, eight transgenic lines confirmed by Southern and Northern blot (T1, T2, T5, T8, T9, T10, T11, and T12) and a non-transformed control plant against peptide degradation by plant peptidases (Sharma et al., 2000). The transgene association with a signal peptide, which targets the gene product to the apoplast, has been utilized in transgenic disease resistance plants in the systems Pseudomonas syringae van Hall pv. tabaci (Wolf and Foster) Young et al./Nicotiana tabacum L. (Huang et al., 1997), E. amylovora/apple (Ko et al., 2000) and X. oryzae (Ishiyama) Swings et al. pv. oryzae (Ishiyama) Swings et al./Oryza sativa L. (Sharma et al., 2000) in order to optimize expression of antibacterial genes. These studies have used signal peptides originally related to plant proteins. The effectiveness of the insect native signal peptide in secreting protein to the intercellular space, in a plant model system, allowed the production of citrus transgenic plants with the proper localization of the attA gene product.

In our study, not all regenerants that sprouted from explants treated with A. tumefaciens showed amplification of attA gene by PCR, indicating that some escapes occurred during the regeneration process in selective medium. The occurrence of escapes is 

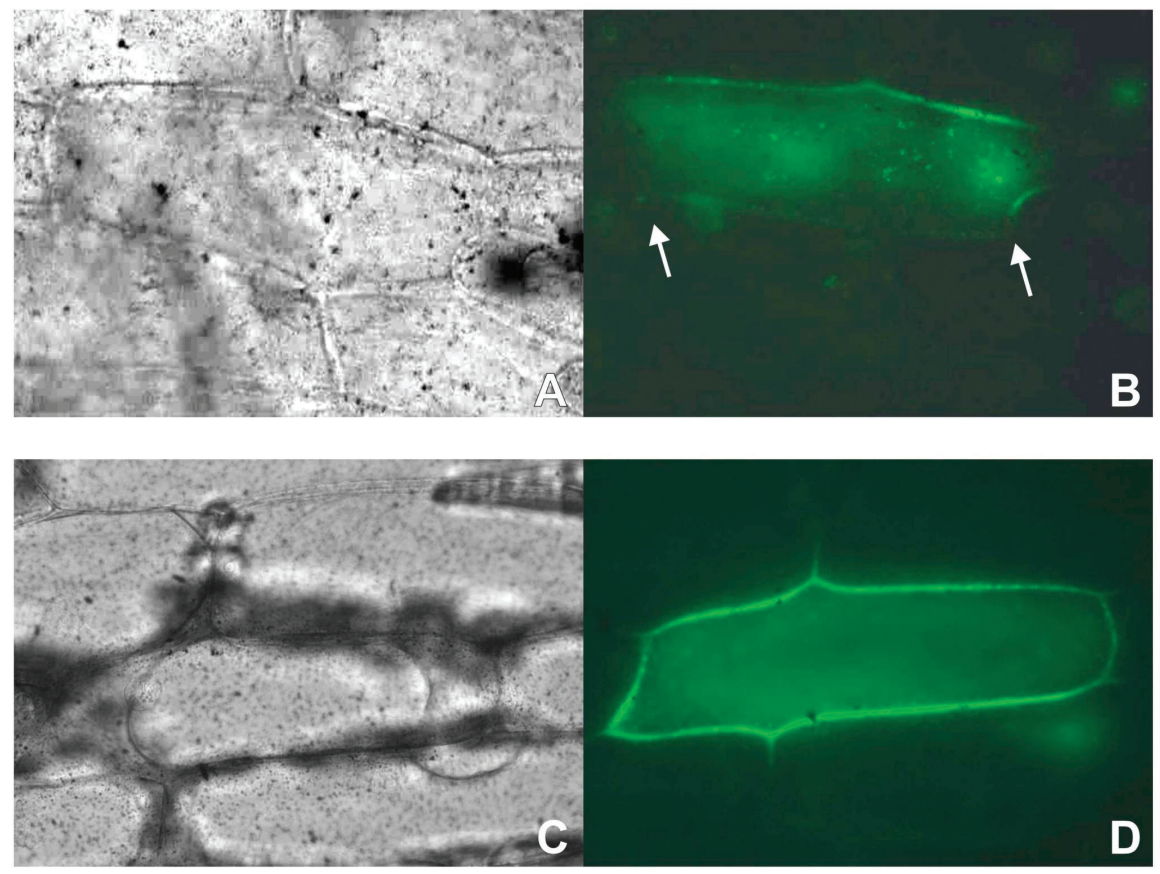

Fig. 2. Onion cells transformed with the plasmids pattA $1303(\mathbf{A}, \mathbf{B})$ and pSPattA $1303(\mathbf{C}, \mathbf{D})$ showing fluorescence accumulation inside (B, arrows) and outside the cells (D). Membranes were induced to shrink from the cell wall (well observe in $\mathbf{C}$ ). White $(\mathbf{A}, \mathbf{C})$ and UV light $(\mathbf{B}, \mathbf{D})$ exposition for microphotographing.
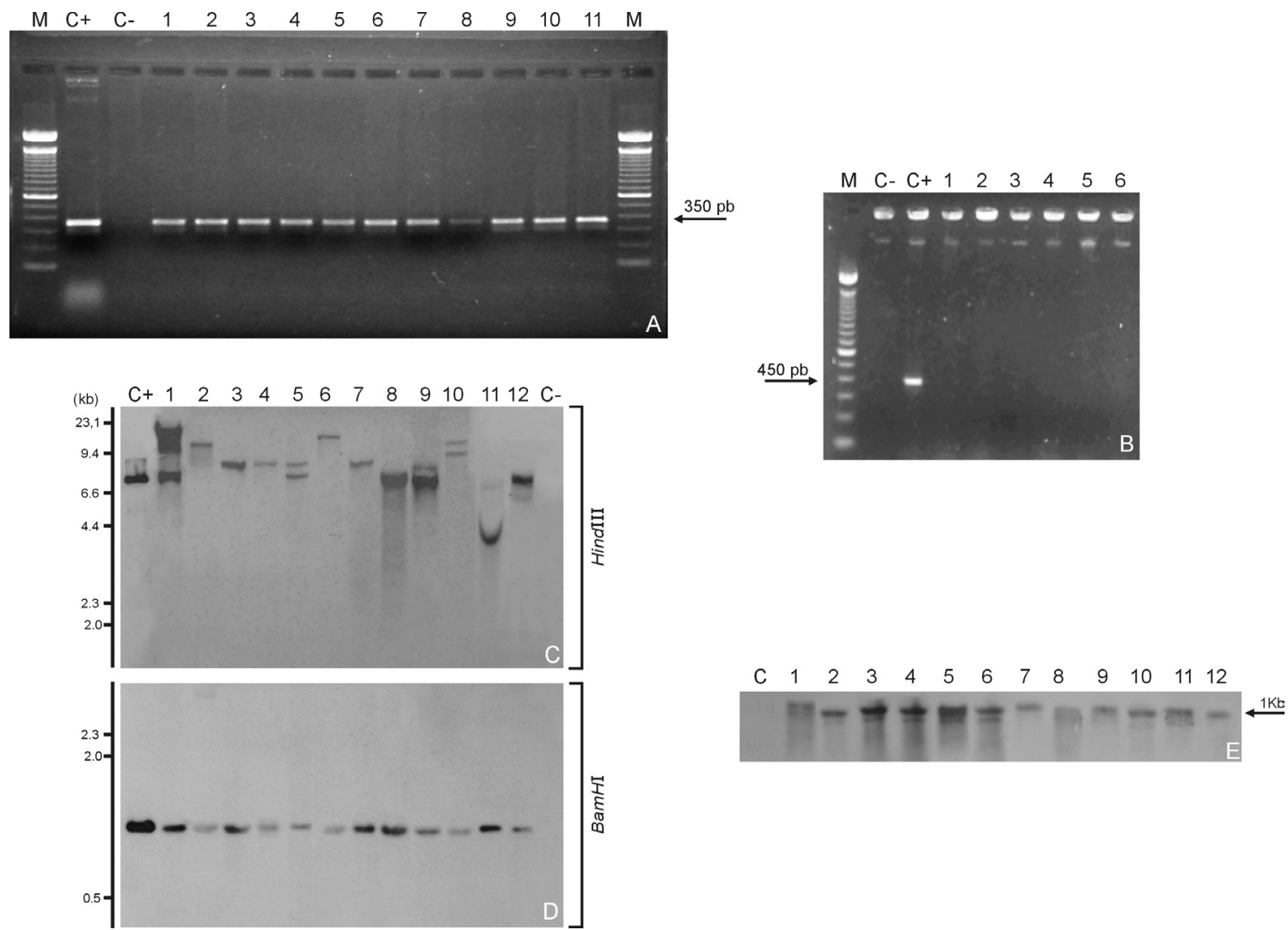

Fig. 3. Analyses of Citrus sinensis 'Hamlin' putative transformants. (A) PCR analyses for attA gene detection; lanes 1-11: DNA from shoots developed after genetic transformation; $\mathrm{M}=100$-bp ladder (Amersham Biosciences); $\mathrm{C}+=$ positive control (pCattA2300); C- = negative control (DNA of non-transformed 'Hamlin'). (B) = PCR analyses for vir G gene detection; $\mathrm{M}=100$-bp ladder; $\mathrm{C}+=$ positive control (Agrobacterium tumefaciens DNA); $\mathrm{C}-=$ negative control (DNA of nontransformed 'Hamlin'); lanes 1-6 = represent transgenic plants. (C, D) Southern blot analyses. $20 \mu \mathrm{g}$ DNA was digested with BamHI or HindIII and hybridized with a probe corresponding to 1050-bp from the attA gene; $\mathrm{C}+=$ positive control (pCattA2300); C- = negative control (DNA of non-transformed 'Hamlin'); lanes 1-12 = DNA from independent transgenic lines digested by HindIII (C) and BamHI (D); Lambda DNA cut with HindIII or BamHI was used as a size marker (given in kilobases). (E) Northern blot analyses. Transcription of attA gene in leaves of control (C) and transgenic lines (lanes 1-12). 

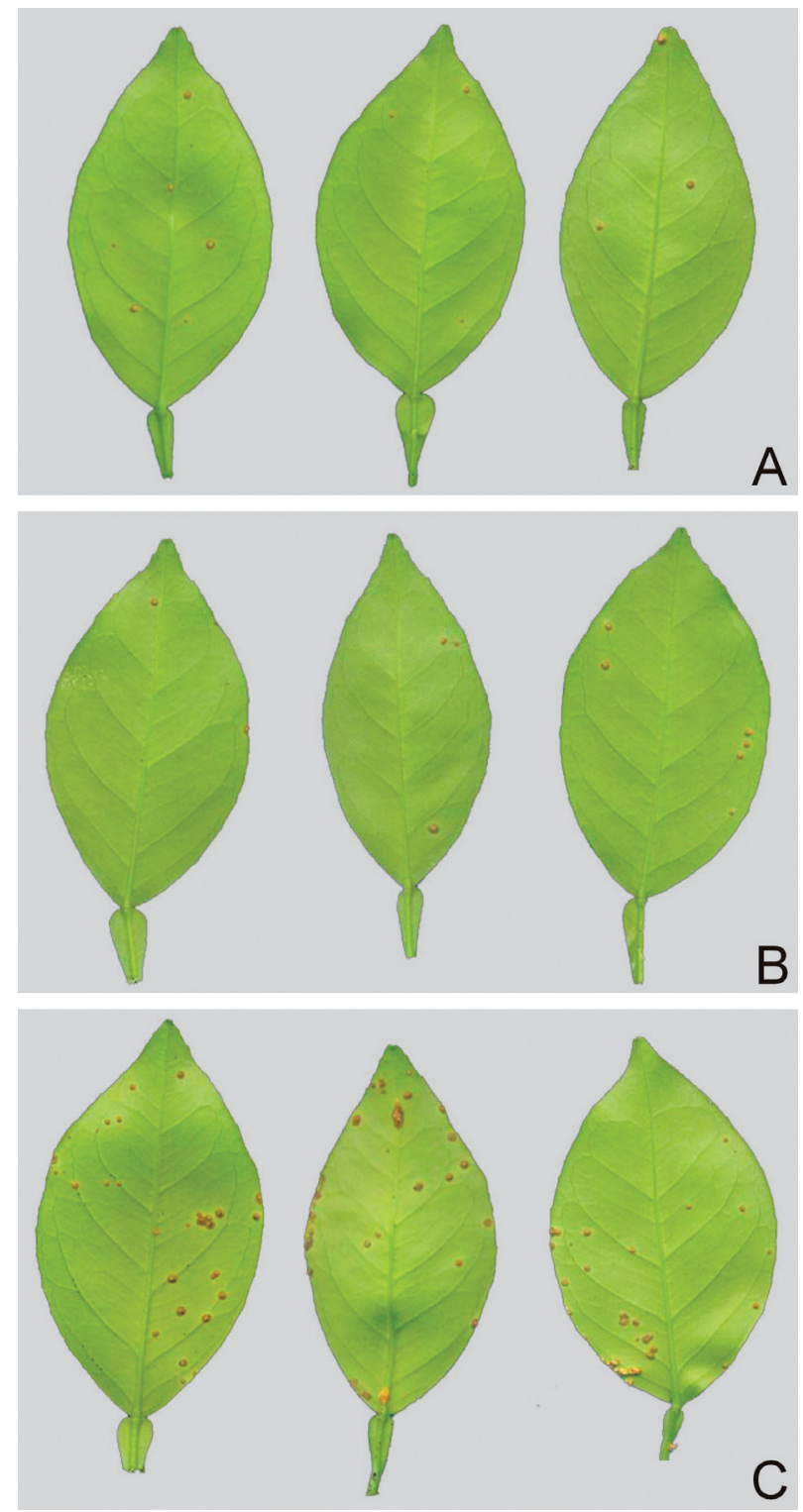

Fig. 4. Citrus canker symptoms on leaves of transgenic lines T2 (A) and T8 (B), containing the attA gene, and a non-transformed control line (C). Leaves were detached and the images digitalized $30 \mathrm{~d}$ after inoculation.

a problem in citrus genetic transformation, probably because of non-transformed cells were protected by the surrounding transformed cells (Domínguez et al., 2004). We have recorded the $A$. tumefaciens-mediated transformation efficiency of $14 \%$. Some $\mathrm{PCR}+$ shoots did not develop into whole plants due to losses at the micrografting and acclimatization stages.

The results obtained in bioassays with X. axonopodis pv. citri suggested that attA-expressing citrus lines showed improved resistance to citrus canker. Transgenic plants demonstrated a significant reduction in disease severity caused by $X$. axonopodis pv. citri compared to non-transformed C. sinensis 'Hamlin.' Quantification of attacin A protein in transgenic plants was not possible due to the lack of purified antiserum in our laboratory. Taken together, Northern blot and bioassay results from all analyzed transgenic lines did not indicate a high correlation between transcription level and disease resistance. Line 12 exhibited a considerable level of disease reduction despite the low transcription level. Disease severity reduction was also detected in transgenic plants

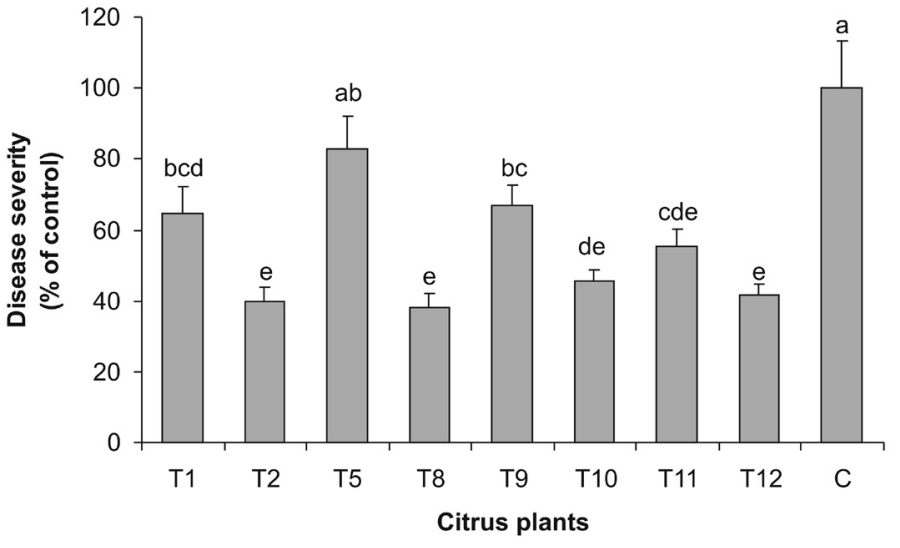

Fig. 5. Citrus canker severity among transgenic lines containing attA gene (T1, T2, T5, T8, T9, T10, T11, and T12) compared to a non-transformed control line (C). Each bar is the mean of 15 leaves of three independent experiments. Error bars indicate standard error of means. Different letters on top of bars represent significantly differences from control plant, at $P<0.05$, according to Tukey's test.

expressing attacin $\mathrm{E}$ gene, as in the studies with the systems apple and pear/E. amylovora (Ko et al., 2002; Reynoird et al., 1999) and potato/E. carotovora (Arce et al., 1999). However, a lack of correlation between transcription level and disease resistance has also been reported in other systems (Malnoy et al., 2003; Reynoird et al., 1999). The precise mechanism of increased disease resistance in the genetic engineered plants is not clear and further studies are necessary.

The results presented in this work are promising and stimulate the use of genetic engineering to control citrus disease problems caused by bacteria. However, the risks of using broad-host-range antibacterial proteins to enhance resistance to phytopathogenic bacteria have to be considered.

\section{Literature Cited}

Alfano, J.R. and A. Collmer. 1996. Bacterial pathogens in plants: Life up against the wall. Plant Cell 8:1683-1698.

Aragão, F.J.L., L.M.G. Barros, A.C.M. Brasileiro, S. Ribeiro, F.D. Smith, J.C. Sanford, J.C. Faria, and E.L. Reich. 1996. Inheritance of foreign genes in transgenic bean (Phaseolus vulgaris L.) co-transformed via bombardment. Theor. Appl. Genet. 152:120-134.

Arce, P., M. Moreno, M. Gutierrez, M. Gebauer, P.Dell'Orto, H. Torres, I. Acuña, P. Oliger, A. Venegas, X. Jordana, J. Kalazich, and L. Holuigue. 1999. Enhanced resistance to bacterial infection by Erwinia carotovora subsp. atroseptica in transgenic plants expressing the attacin or the cecropin SB-37 genes. Amer. J. Potato Res. 76:169-177.

Asling, B., M.S. Dushay, and D. Hultmark. 1995. Identification of early genes in the Drosophila immune response by PCR-based differential display: The attacin A gene and the evolution of attacin-like protein. Insect Biochem. Mol. Biol. 35:511-518.

Boscariol, R.L., W.A.B. Almeida, M.T.V.C. Derbyshire, F.A.A. Mourão Filho, and B.M.J. Mendes. 2003. The use of the PMI/mannose selection system to recover transgenic sweet orange plants (Citrus sinensis L. Osbeck). Plant Cell Rpt. 22:122-128.

Brandizzi, F., S.L. Irons, L. Johansen, A. Kotzer, and U. Neumann. 2004. GFP is the way to glow: Bioimaging of the plant endomembrane system. J. Microsc. 214:138-158.

Brasileiro, A.C.M. and V.T.C. Carneiro. 1998. Manual de transformação genética de plantas. Embrapa, Brasília, Brazil.

Carlsson, A., T. Nyström, H. Cock, and H. Bennich. 1998. Attacin-an insect immune protein-binds LPS and triggers the specific inhibi- 
tion of bacterial outer-membrane protein synthesis. Microbiology 144:2179-2188.

Domínguez, A., J. Guerri, M. Cambra, L. Navarro, P. Moreno, and L. Peña. 2000. Efficient production of transgenic citrus plats expressing the coat protein gene of citrus tristeza virus. Plant Cell Rpt. 19:427-433.

Domínguez, A., A.H. Mendoza, J. Guerri, M. Cambra, L. Navarro, P. Moreno, and L. Peña. 2002. Pathogen-derived resistance to citrus tristeza virus (CTV) in transgenic mexican lime (Citrus aurantifolia (Christ.) Swing.) plants expressing its p25 coat protein gene. Mol. Breeding 10:1-10.

Domínguez, A., M. Cervera, R.M. Pérez, J. Romero, C. Fagoaga, J. Cubero, M.M. López, J.A. Juarez, L. Navarro, and L. Peña. 2004. Characterisation of regenerants obtained under selective conditions after Agrobacterium-mediated transformation of citrus explants reveals production of silenced and chimeric plants at unexpected high frequencies. Mol. Breeding 14:171-183.

Doyle, J.J. and J.L. Doyle. 1990. Isolation of plant DNA from fresh tissue. Focus 12:13-15.

During, K. 1996. Genetic engineering for resistance to bacteria in transgenic plants by introduction of foreign genes. Mol. Breeding 2:297-305.

Engström, P., A. Carlsson, Ä. Engström, Z.J. Tao, and H. Bennich. 1984. The antibacterial effect of attacins from the silk moth Hyalophora cecropia is directed against the outer membrane of Escherichia coli. EMBO J. 3:3347-3351.

Fagoaga, C., I. Rodrigo, V. Conejero, C. Hinarejos, J.J. Tuset, J. Arnau, J.A. Pina, L. Navarro, and L. Peña. 2001. Increased tolerance to Phytophthora citrophthora in transgenic orange plants constitutively expressing a tomato pathogenesis related protein PR-5. Mol. Breeding 7:175-185.

Fagoaga, C., C. López, A.H. Mendoza, P. Moreno, L. Navarro, R. Flores, and L. Peña. 2006. Post-transcriptional gene silencing of the 23 silencing suppressor of citrus tristeza virus confers resistance to the virus in transgenic mexican lime. Plant Mol. Biol. 60:153-165.

Grosser, J.W. and F.G. Gmitter.1990. Protoplast fusion and citrus improvement. Plant Breeding Rev. 8:339-374.

Huang, Y., R.O. Nordeen, M. Di, L.D. Owens, and J.H. McBeath. 1997. Expression of an engineered cecropin gene cassette in transgenic tobacco plants confers disease resistance to Pseudomonas syringae pv. tabaci. Phytopathology 87:494-499.

Hultmark, D., A. Engström, K. Andersson, H. Steiner, H. Bennich, and H.G. Boman. 1983. Insect immunity. Attacins, a family of antibacterial proteins from Hyalophora cecropia. EMBO J. 2:571-576.

Kang, D., A. Lundström, and H. Steiner. 1996. Trichoplusia ni attacin A, a differentially displayed insect gene coding for an antibacterial protein. Gene 174:245-249.

Ko, K., J.L. Norelli, J.P. Reynoird, E. Boresjza-Wysocka, S.K. Brown, and H.S. Aldwinckle. 2000. Effect of untranslated leader sequence of
AMV RNA 4 and signal peptide of pathogenesis-related protein $1 \mathrm{~b}$ on attacin gene expression, and resistance to fire blight in transgenic apple. Biotechnol. Lett. 22:373-381.

Ko, K., J.L. Norelli, J.P. Reynoird, H.S. Aldwinckle, and S.K. Brown. 2002. T4 lysozyme and attacin genes enhance resistance of transgenic 'Galaxy' apple against Erwinia amylovora. J. Amer. Soc. Hort. Sci. 127:515-519.

Malnoy, M., J.S. Venisse, M.N. Brisset, and E. Chevreau. 2003. Expression of bovine lactoferrin cDNA confers resistance to Erwinia amylovora in transgenic pear. Mol. Breeding 12:231-244.

Mourgues, F., M.N. Brisset, and E. Chevreau. 1998. Activity of different antibacterial peptides on Erwinia amylovora growth, and evaluation of the phytotoxicity and stability of cecropins. Plant Sci. 139:83-91.

Negrotto, D., M. Jolley, S. Beer, A.R. Wenck, and G. Hamsen. 2000. The use of phosphomannose-isomerase as a selectable marker to recover transgenic maize plants (Zea mays L.) via Agrobacterium transformation. Plant Cell Rept. 19:798-803.

Peña, L., M. Cervera, J. Juarez, A. Navarro, J.A. Pina, N. Durán-Vila, and L. Navarro. 1995. Agrobacterium-mediated transformation of sweet orange and regeneration of transgenic plants. Plant Cell Rpt. 14:616-619.

Reynoird, J.P., F. Mourgues, J. Norelli, H.S. Aldwinckle, M.N. Brisset, and E. Chevreau. 1999. First evidence for improved resistance to fire blight in transgenic pear expressing the attacin E gene from Hyalophora cecropia. Plant Sci. 149:23-31.

Sharma, A., R. Sharma, M. Imamura, M. Yamakawa, and H. Machii. 2000. Transgenic expression of cecropin B, an antibacterial peptide from Bombyx mori, confers enhanced resistance to bacterial leaf blight in rice. FEBS Lett. 484:7-11.

Silva-Filho, M.C. 2003. One ticket for multiple destinations: Dual targeting of proteins to distinct subcellular locations. Current Opin. Plant Biol. 6:589-595.

Smith F.D., A. Jofre-Garfias, and J.C. Sanford. 1992. Transformation of bean apical dome cells by microparticle bombardment. Phytopathology 82:1167-1168.

Sun, S.C., I. Lindström, J.Y. Lee, and I. Faye. 1991. Structures and expression of the attacin genes in Hyalophora cecropia. Eur. J. Biochem. 196:247-254.

Timmermans, M.C.P., P. Maliga, J. Vieira, and J. Messing. 1990. The pFF plasmids: Cassettes utilizing CaMV sequences for expression of foreign genes in plants. J. Biotechnol. 14:333-344.

Vale, F.X.R., E.I. Fernandes Filho, J.R. Liberato, and L. Zambolin. 2001. QUANT - A software to quantify plant disease severity. In: Intl. Wkshp. on Plant Dis. Epidemiology 8, Ouro Preto, MG, Brazil, Proc. Intl. Soc. Plant Pathol., p. 160. (Abstr.).

Viloria, Z., D.L. Drouillard, J.H. Graham, and J.W. Grosser. 2004. Screening triploid hybrids of 'Lakeland' limequat for resistance to citrus canker. Plant Dis. 88:1056-1060. 